\title{
NEW RECORD OF THE KIZILIRMAK KILLIFISH (Aphanius marassantensis Pfleiderer, Geiger \& Herder, 2014) FROM SÜREYYABEY DAM LAKE IN YEŞILIRMAK BASIN
}

\author{
Semra BENZER \\ Department of Science Education, Education Faculty, Gazi University, Turkey, sbenzer@gazi.edu.tr \\ (iD) https://orcid.org/0000-0002-8548-8994
}

Received: 19.12.2017, Accepted: 21.03.2018

*Corresponding author

Research Article DOI: $10.22531 /$ muglajsci.396426

\begin{abstract}
The aim of this study was carried out in 2016 to quantify morphometric characteristics of Aphanius marassantensis from Süreyyabey Dam Lake. Some morphometric characters of samples were measured. These characteristics were standard length (SL), total length (TL) body weight (W), head length, preorbital distance, eye diameter, postorbital distance, head depth, predorsal distance, prepelvic distance, preanal distance, pectoral fin - pelvic fin distance, pelvic fin - anal fin distance, body depth, dorsal fin (anterior end) - anal fin distance, dorsal fin (posterior end) - anal fin distance, postdorsal distance, postanal distance, caudal peduncle length (dorsal), caudal peduncle length (ventral), caudal peduncle depth, dorsal fin base length, anal fin base length, pectoral fin length, pelvic fin length, dorsal fin length, anal fin length. The SL of 100 individuals ranged from 22 to $38 \mathrm{~mm}$. The TL of individuals were between 28 and $45 \mathrm{~mm}$, and W ranged between 0.37 and $1.91 \mathrm{~g}$. Total fish examined, $30 \%$ were males, $70 \%$ females.

Keywords: Aphanius marassantensis, Kizılırmak killifish, morphometric characteristic, Süreyyabey Dam Lake

\section{YEŞİLIRMAK HAVZASI SÜREYYABEY BARAJ GÖLÜ'NDEN KIZILIRMAK KILLIFISH (Aphanius marassantensis Pfleiderer, Geiger \& Herder, 2014)'IN YENI KAYDI}

$\ddot{0} \mathbf{z}$

Bu çalışmanın amacl, 2016 yılında Süreyyabey Baraj Gölü'ndeki Aphanius marassantensis'in morfometrilerini belirlemektir. Balık örneklerinin bazı morfometrik karakterleri ölçülmüștür. Standart boy (SL), toplam boy (TL), vücud ağırlığı (W), baş boyu, preorbital mesafe, göz çapı, postorbital mesafe, baş yüksekliği, predorsal mesafe, prepelvik mesafe, preanal mesafe, pektöral yüzgeç, pelvik yüzgeç arası mesafe, pelvik yüzgeç anal yüzgeç mearası mesafe, vücud yüksekliği, dorsal yüzgeç (anterior sonu) - anal yüzgeç arası mesafe, dorsal yüzgeç (posterior sonu) anal yüzgeç mesafe, postdorsal mesafe, postanal mesafe, kaudal sap boyu (dorsal), kaudal sap boyu (ventral), kaudal sap yüksekliği, dorsal yüzgeç taban boyu, anal yüzgeç taban boyu, pektoral yüzgeç özellikleri ele alınmıştır. 100 adet balık örneklerinin standart boy, tam boy ve ağırlık değerleri sırasıyla 22 - 38 mm; 28 - 45 mm; 0,37 -1,91 g olarak tespit edilmiștir. Íncelenen tüm bireylerin \%30 erkek \%70'i dişidir.

Anahtar Kelimeler: Aphanius marassantensis, Kızllırmak killifish, morfometrik karekter, Süreyyabey Baraj Gölü

Cite

Benzer, S., (2018). "New Record of The Kizilirmak Killifish (Aphanius marassantensis Pfleiderer, Geiger \& Herder, 2014) From Süreyyabey Dam Lake in Yeşilırmak Basin", Mugla Journal of Science and Technology, 4(1), 41-45.

\section{Introduction}

Anatolia; geologic events are characterized by a diversity of living organisms due to their presence in the continents as well as climate characteristics [1]. In most of the Cyprinodontidae species, a large salinity and temperature tolerance are observed. Because of their small size, they can successfully populate in restricted habitats [2].

While sexual dimorphism is weak in size, it is apparent in terms of size, coloring and fin size [3-5]. Aphanius belongs to the family Cyprinodontidae. Aphanius species are generally omnivorous [5]. It is under threat in many types Aphanius in Turkey and world [6].

Aphanius is represented by at minimum 14 existing species in Anatolia for the present, 12 of which are indigenous [7-8]. Hrbek et al. [9] reported on an Aphanius population from lower Yeşilırmak River. It was found that one population of Aphanius marassantensis from central Yeşilırmak Basin [10].

Morphometric characters of fish represent one of the main keys for identifying their systematics, growth changefulness, ontogenetic trajectories [11] and several growth parameters. Both, taxonomic classification of 
organisms and comprehending the variety of biological life, were ground on descriptions of morphological forms from a historical perspective [12].

Population diversity might also be caused by sexual dimorphism, which is prevalent across the animal universe. The disparity between males and females is not only in reproductive organs, but also in outer structures that are not directly pertain to reproduction [13].

Despite the fact that the Aphanius genus does not have economic precaution, it has been subject to many researches. There are many national and international studies on various properties of Aphanius species [3,7,9, 14-34].

There are many studies on various characteristics of Aphanius species both at global studies and international studies. However, this is the first record of the species from Süreyyabey Dam Lake.

Located in inland water resources in Turkey, the life cycle of fish species and determination of biological characteristics are important. In this paper, we report first occurrence from Süreyyabey Dam Lake in Yeşilırmak Basin. The main purpose of this study is to determine whether there is a difference between morphological characters between male and female. This paper describes the area where this fish was found and recorded morphometric data of the population.

\section{Material and Methods}

Süreyyabey Dam Lake is located approximately $82 \mathrm{~km}$ northeast of Yozgat (3528' N and 353' N latitudes and 395' E and 400' E longitudes) (Fig. 1). Süreyyabey Dam, Yozgat province on the Çekerek Creek, irrigation, energy and flood control was done. The area of lake is $41,34 \mathrm{~km}^{2}$ with a rock body fill type dam. The Çekerek River, one of the important branches of Yeşilırmak, is located between the Deveci Mountains (1892 m) and Dagni Mountain (1755 m) [35].

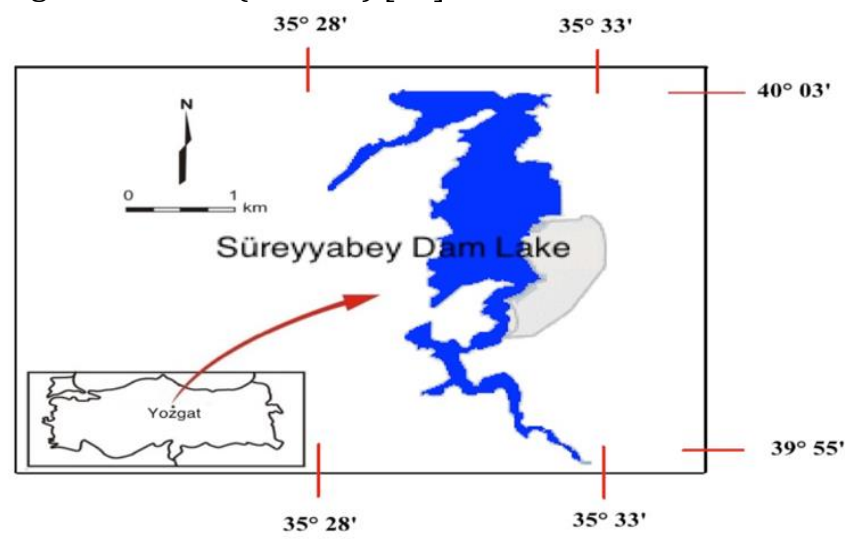

Figure 1. Map of Süreyyabey Dam Lake

Fish specimens $(n=100 ;$ males $=30$; females $=70)$ were captured by commercial fisherman from Süreyyabey Dam Lake in 2016. Sex determination was based on external coloration of individuals. The samples were preserved in $4 \%$ formaldehyde solution and transported to the laboratory; weight was measured to the nearest
$0.001 \mathrm{~g}$ and total and standard length to the nearest 0.01 mm. In total, Twenty-seven (27) morphometric characters of samples were measured. These characteristics were standard length (SL), total length (TL) body weight (W), head length, preorbital distance, eye diameter, postorbital distance, head depth, predorsal distance, prepelvic distance, preanal distance, pectoral fin - pelvic fin distance, pelvic fin - anal fin distance, body depth, dorsal fin (anterior end) - anal fin distance, dorsal fin (posterior end)-anal fin distance, postdorsal distance, postanal distance, caudal peduncle length (dorsal), caudal peduncle length (ventral), caudal peduncle depth, dorsal fin base length, anal fin base fin length, pectoral fin length, pelvic fin length, dorsal fin length, anal fin length. The SL of 100 individuals ranged from 20 to $38 \mathrm{~mm}$. The TL of individuals were between 28 and $45 \mathrm{~cm}$, and W ranged between 0.37 and $1.91 \mathrm{~g}$. subsequently.

\section{Results and Discussion}

Aphanius marassantensis, previously included in $A$. danfordii. Male A. marassantensis has 8-13 dark-brown sidelong bars than $A$. meridionali and $A$. sureyanus, has 23 upright rows of spots on the back fin, and predominantly has 8-13 sidelong bars than $A$. villwocki. A. marassantensis is separated from $A$. saldae by having a less slim and lengthen body shape (Body depth/Standard length $28.2-39.6 \%$ vs. 20.1-21.3\%), body with whole scale cover, and 25-28 scales along the sidelong series [8]. Pfleiderer et al. [8] reports the diagnostic properties of $A$. marasantensis as Dorsal soft rays (total): 9-11; Anal soft rays: 9-11; Vertebrae: $25-27$.

In this research, some morphometric characters were examined and the minimum, maximum, mean, standard deviation values are given in Table 1 . Measurements and counts of the 100 specimens are given Table 1 . Total fish examined, $30 \%$ were males, $70 \%$ females. Total lengths and weights of the examined specimens ranged 2.80 and $4.5 \mathrm{~cm} ; 0.37$ and $1.91 \mathrm{~g}$ respectively.

The fish in the vertebrate group are represented by 33200 species identified to date in the World [36]. Küçük [37] noted that $10 \%$ of the endemic freshwater fish belong to the Cyprinodontidae family and that the endemism rate of the family is $78 \%$, taking into account the red-listed situations of endemic freshwater fish. When IUCN red list of 2013 is examined; 9 Aphanius species ranging in Turkey, where the list of 7 , critically endangered of 2 of them (CR) where, endangered a species (EN) where insufficient data on other species (DDR) seems to be found [38]. They live in freshwaters, brackish waters and marine coastal regions. They are scattered all over the world in the USA, Central America, West Indies, northern parts of South America, North Africa, Southern Europe and Anatolia [39]. 
Table 1. Metric characters of Aphanius marasantensis specimens

\begin{tabular}{|c|c|c|c|c|c|c|c|c|c|c|c|}
\hline \multirow{2}{*}{$\mathrm{Nu}$} & \multirow{2}{*}{ PARAMETERS } & \multicolumn{5}{|c|}{ Female } & \multicolumn{5}{|c|}{ Male } \\
\hline & & $\min$ & $\max$ & mean & SD & $\mathrm{CI}$ & $\min$ & $\max$ & mean & SD & $\mathrm{CI}$ \\
\hline 1 & Standard Length & 2.50 & 3.80 & 2.980 & 0.3047 & 0.0714 & 2.20 & 3.0 & 2.67 & 0.1988 & 0.0711 \\
\hline 2 & Total Length & 2.90 & 4.50 & 3.487 & 0.3379 & 0.0792 & 2.80 & 3.6 & 3.16 & 0.2016 & 0.0721 \\
\hline 3 & Body Weight & 0.41 & 1.91 & 0.846 & 0.3036 & 0.0711 & 0.37 & 1.0 & 0.60 & 0.1307 & 0.0468 \\
\hline 4 & Head Length & 0.40 & 1.10 & 0.829 & 0.1416 & 0.0332 & 0.60 & 0.9 & 0.75 & 0.0900 & 0.0322 \\
\hline 5 & Preorbital Distance & 0.10 & 0.40 & 0.272 & 0.0623 & 0.0146 & 0.20 & 0.4 & 0.24 & 0.0553 & 0.0198 \\
\hline 6 & Eye Diameter & 0.20 & 0.30 & 0.217 & 0.0339 & 0.0079 & 0.15 & 0.3 & 0.22 & 0.0351 & 0.0126 \\
\hline 7 & Postorbital Distance & 0.30 & 1.00 & 0.443 & 0.1430 & 0.0335 & 0.30 & 0.5 & 0.36 & 0.0706 & 0.0253 \\
\hline 8 & Head Depth & 0.50 & 1.00 & 0.726 & 0.0973 & 0.0228 & 0.60 & 7.0 & 0.90 & 1.1558 & 0.4136 \\
\hline 9 & Predorsal Distance & 0.20 & 2.50 & 1.931 & 0.3197 & 0.0749 & 1.50 & 2.9 & 1.78 & 0.3174 & 0.1136 \\
\hline 10 & Prepelvic Distance & 0.50 & 2.20 & 1.625 & 0.2730 & 0.0644 & 1.20 & 1.7 & 1.49 & 0.1337 & 0.0478 \\
\hline 11 & Preanal Distance & 1.00 & 3.00 & 2.184 & 0.3335 & 0.0781 & 1.70 & 2.2 & 1.96 & 0.1628 & 0.0582 \\
\hline 12 & Pectoral Fin-pelvic fin Distance & 0.60 & 1.20 & 0.849 & 0.1472 & 0.0347 & 0.50 & 1.7 & 0.75 & 0.2686 & 0.0961 \\
\hline 13 & Pelvic Fin- Anal Fin Distance & 0.30 & 0.90 & 0.529 & 0.1226 & 0.0289 & 0.20 & 0.6 & 0.47 & 0.0844 & 0.0302 \\
\hline 14 & Body Depth & 0.70 & 1.30 & 0.961 & 0.1438 & 0.0337 & 0.70 & 1.2 & 0.86 & 0.1082 & 0.0387 \\
\hline 15 & $\begin{array}{l}\text { Dorsal Fin (Anterior End) - } \\
\text { Anal Fin Distance }\end{array}$ & 0.40 & 1.10 & 0.824 & 0.1401 & 0.0328 & 0.60 & 1.1 & 0.80 & 0.1220 & 0.0437 \\
\hline 16 & $\begin{array}{l}\text { Dorsal Fin (Posterior End) - } \\
\text { Anal Fin Distance }\end{array}$ & 0.30 & 1.00 & 0.729 & 0.1483 & 0.0347 & 0.50 & 1.0 & 0.70 & 0.1238 & 0.0443 \\
\hline 17 & Postdorsal Distance & 0.70 & 1.90 & 0.956 & 0.2256 & 0.0529 & 0.60 & 1.0 & 0.78 & 0.1112 & 0.0398 \\
\hline 18 & Postanal Distance & 0.50 & 0.90 & 0.741 & 0.1195 & 0.0280 & 0.50 & 0.8 & 0.65 & 0.0922 & 0.0330 \\
\hline 19 & Caudal Peduncle Length (Dorsal) & 0.60 & 1.10 & 0.787 & 0.1141 & 0.0267 & 0.50 & 0.9 & 0.67 & 0.1028 & 0.0368 \\
\hline 20 & Caudal Peduncle Length (Ventral) & 0.30 & 0.90 & 0.638 & 0.1320 & 0.0309 & 0.40 & 0.7 & 0.59 & 0.1062 & 0.0380 \\
\hline 21 & Caudal Peduncle Depth & 0.30 & 0.60 & 0.413 & 0.0711 & 0.0166 & 0.30 & 0.7 & 0.42 & 0.0939 & 0.0336 \\
\hline 22 & Dorsal Fin Base Length & 0.10 & 0.60 & 0.329 & 0.1024 & 0.0240 & 0.10 & 0.5 & 0.36 & 0.0894 & 0.0320 \\
\hline 23 & Anal Fin Base Length & 0.20 & 0.60 & 0.314 & 0.0885 & 0.0207 & 0.20 & 0.4 & 0.30 & 0.0676 & 0.0242 \\
\hline 24 & Pectoral Fin Length & 0.30 & 0.70 & 0.514 & 0.0993 & 0.0233 & 0.20 & 0.7 & 0.45 & 0.1013 & 0.0362 \\
\hline 25 & Pelvic Fin Length & 0.10 & 2.30 & 0.272 & 0.2676 & 0.0631 & 0.10 & 0.4 & 0.23 & 0.0807 & 0.0289 \\
\hline 26 & Dorsal Fin Length & 0.30 & 0.70 & 0.484 & 0.1072 & 0.0251 & 0.30 & 0.7 & 0.55 & 0.1118 & 0.0400 \\
\hline 27 & Anal Fin Length & 0.30 & 0.70 & 0.503 & 0.0989 & 0.0232 & 0.30 & 0.7 & 0.52 & 0.0834 & 0.0298 \\
\hline
\end{tabular}

SD: Std Deviation; CI: Confidence Interval

\section{References}

Süreyyabey Dam Lake in Yeşilırmak Basin. This paper describes the area where this fish was found and recorded morphometric data of the population. Findings obtained in this study are very important because the previous studies about the morphometric properties of A. marassantensis have not been found. It is considered that the data obtained in this study will also contribute to future studies.

\section{Acknowledgment}

This study has been accepted for oral presentation at The International Conference on Civil and Environmental Engineering (ICOCEE-Cappadocia 2017), Nevşehir, Turkey.

[1] Demirsoy, A., "Genel Zoocoğrafya ve Türkiye Zoocoğrafyası - Hayvan Coğrafyası", Meteksan A. Ş. Ankara, 1007 s. 2002.

[2] Parker, A., Kornfield I., "Molecular perpective on evolution and zoogeography of Cyprinodontid killifishes (Teleostei; Atherinomorpha )", Copeia, Vol. 1995, pp 8-21. 1995.

[3] Hrbek, T. \& Meyer, A. "Closing of the Tethys Sea and the phylogeny of Eurasian killifishes (Cyprinodontiformes: Cyprinodontidae)", Journal of Evolutionary Biology, 16, 17-36., 2003.

[4] Kottelat, M \& Freyhoff, J., "The Handbook of the Eeuropean Freshwater Fishes", Steven Simpson Books, Norwich. 2007.

[5] Leonardos, I. "The feeding ecology of Aphanius fasciatus (Valenciennes, 1821) in the lagoonal system of Messolongi (western Greece)", Sci Mar, 72:393-401, 2008.

[6] Freyhof, J. \& Brooks, E., "European red List of Freshwater Fishes", Luxembourg: Publications Office of the european Union. 2011.

[7] Geiger, M.F., Herder, F., Monaghan, M.T., Almada, V., Barbieri, R., Bariche, M., Berrebi, P., Bohlen, J., CasalLopez, M., Delmastro, G.B., Denys, G. P.J., Dettai, A., Doadrio, I., Kalogianni, E., Kärst, H., Kottelat, M., Kovačić, M., Laporte, M., Lorenzoni, M., Marčić, Z., Özuluğ, M., Perdices, A., Perea, S., Persat, H., Porcellotti, S., Puzzi, C., Robalo, J., Šanda, R., Schneider, M., Šlechtová, V., Stoumboudi, M., Walter, 
S. \& Freyhof, J. "Spatial heterogeneity in the Mediterranean Biodiversity Hotspot affects barcoding accuracy of its freshwater fishes", Molecular Ecology Resources, 14 (6): 1210-1221, 2014.

[8] Pfleiderer, S., Geiger, M. \& Herder, F. “Aphanius marassantensis, a new toothcarp from the Kızılırmak drainage in northern Anatolia (Cyprinodontiformes: Cyprinodontidae)", Zootaxa. 3887(5):569-582, 2014.

[9] Hrbek, T., Küçük, F., Frickey, T., Stölting, K.N., Wildekamp, R.H. \& Meyer, A. "Molecular phylogeny and historical biogeography of the Aphanius (Pisces, Cyprinodontiformes) species complex of central Anatolia, Turkey", Molecular Phylogenetics and Evolution. 25(1):125-137, 2002.

[10] Yoğurtçuoğlu, B., \& Ekmekçi, F. G. "New Records of Kızılırmak Toothcarp, Aphanius marassantensis from Central Yeşilırmak River Basin (Turkey)" Turkish Journal of Fisheries and Aquatic Sciences, 17(1), 205-208, 2017.

[11] Kovac V, Copp GH, Francis MP, "Morphometry of the stone loach Barbatula barbatula: do mensural characters reflect the species' life history thresholds?", Environmental Biology of Fishes 56: 105-115, 1999.

[12] Dean, C.A., Rholf, F.J. and Dennis, E.S. "Geometric morphometrics: Ten years of progress following the revolution”, Ital. J. Zool., 71: 5-16, 2004.

[13] Kitano J, Mori S, Peichel CL. "Sexual dimorphism in the external morphology of the threespine stickleback (Gasterosteus aculeatus)", Copeia. 2007:336-349. 2007.

[14] Pellegrin, D. J. "Les Poissons Des Eaux Douces d'asieMineure". Voy. Zool. Gedeau de Kerville, Tome II, Paris, 150 p. 1928.

[15] Sözer, F. “Contributions a la connaissance des Cyprinodontides de la Turquie" Rev. Fac. Sci. Univ. Istanbul Série B, Tome VII, Fasc. 4, 308- 316. 1942.

[16] Akşiray, F. "Türkische Cyprinodontiden I", İstanbul Üniversitesi Fen Fakültesi Mecmuası Seri B, XIII (2): 98-142. 1948.

[17] Wildekamp, R.H., Kücük, F., Ünlüsayin, M. \& Van Neer, W. "Species and subspecies of the genus Aphanius Nardo 1897 (Pisces: Cyprinodontidae) in Turkey", Turkish Journal of Zoology, 23, 23-44, 1999.

[18] Leonardos, I, A. Sinis. "Population age and sex structure of Aphanius fasciatus Nardo, 1827 (Pisces: Cyprinodontidae) in the Mesolongi and Etolikon lagoons (W. Greece)", Fisheries Research (40): 227235. 1999.

[19] Hrbek, T., R. H. Wildekamp. “Aphanius willwocki, a new species from the Sakarya River basin of central Anatolian plain, Turkey (Teleostei: Cyprinodontiformes)", Ichthyological Exploration Freshwaters, 14 (2): 137-144, 2003.
[20] Esmaeili, H.R. and Shiva, A.H. "Reproductive biology of the Persian Tooth-carp, Aphanius persicus (Jenkins, 1910) (Cyprinodontidae) in southern Iran", Zool. Mid. East. 37: 39-46. 2006.

[21] Sari, M, H., Ilhan, A., Yesilova, B., "Some biological features of mediterranean toothcarp Aphanius fasciatus (Valenciennes, 1821)", Ege University Faculty of Fisheries Journal of Fisheries and Aquatic Sciences 24(3-4):311-314. 2007.

[22] Güçlü, S.S., Turna, İ.İ., Güçlü, Z. and Gülle, İ. "Population Structure and Growth of Aphanius anatoliae sureyanus Neu, 1937 (Osteichthyes: Cyprinodontidae), Endemic to Burdur Lake, Turkey" Zoology in the Middle East, 41: 63-69. 2007.

[23] Güçlü, S. S., \& Küçük, F. "Population Age, Sex Structure, Growth and Diet of Aphanius mento Heckel in: Russegger, 1843 (Cyprinodontidae: Teleostei), to Kırkgöz Spring, Antalya-Türkiye", Turkish Journal of Fisheries and Aquatic Sciences, 8(2), 2008.

[24] Karslı, Z. and Aral, O., "Population age, sex structure and growth of Aphanius danfordii (Boulenger, 1890) to Sirakaraağaçlar Stream, Turkey" Journal and Animal Veterinary Advances, 9(10), 1427-1431, 2010.

[25] Yoğurtçuoğlu, B. \& Ekmekçi, F.G. "Life-history traits of Aphanius danfordii (Boulenger, 1890) (Pisces: Cyprinodontidae), endemic to Kizılırmak Basin (Turkey)" Journal of Applied Ichthyology. 29(4):866- 871, 2013.

[26] Golmoradizadeh A., Kamrani E., Sajjadi M.M., "Life story traits of Aphanius ginaonis Holly,1929 (Cyprinodontidae) and potential risks of extinction in the Geno hot spring Iran population", Journal Applied Ichthyol. 28:31-33, 2012.

[27] Yoğurtçuoğlu, B. Ekmekçi, F.G, "First Attempt at Conservation of a Critically Engangered Cyprinodontid in Turkey", J. Biol. Environ. SCI, 8(24), 159-163, 2014.

[28] Esmaeili, H.R., Teimori, A., Gholami, Z. \& Reichenbacher, B. "Two new species of the toothcarp Aphanius (Teleostei: Cyprinodontidae) and the evolutionary history of the Iranian inland and inland-related Aphanius species" Zootaxa, 3786 (3), 246-268, 2014.

[29] Erbay, F.K., “Endemik Bir Balık Türü Olan Aphanius villwocki'nin Özdere (Sakarya Nehri Havzasi ) Populasyonunun Büyüme ve Üreme Özellikleri”, Hacettepe Üniv. Yüksek Lisans Tezi. 2014.

[30] Teimori, A., Esmaeili, H.R., Erpenbeck, D. \& Reichenbacher, B. "A new and unique species of the genus Aphanius Nardo, 1827 (Teleostei: Cyprinodontidae) from Southern Iran: A case of regressive evolution. Zoologischer Anzeiger - $A$ Journal of Comparative Zoology, 253, 327-337, 2014. 
[31] Ergüden, S. A. “Seyhan Baraj Gölü (Adana)'ndeki Aphanius mento (Heckel, 1843)'nun Bazl Morfometrik Özellikleri”, Düzce Üniversitesi Bilim ve Teknoloji Dergisi, 3(1), 2014.

[32] Yoğurtçuoğlu, B., \& Ekmekçi, F. G. "Length-weight and length-length relationships of eight endemic Aphanius species from Turkey", Journal of applied ichthyology, 31(4), 811-813, 2015.

[33] Keivany, Y., \& Zamani-Faradonbeh, M. "Lengthweight and length-length relationships for four fish species from Talkhehrud River, Urmia Lake Basin, Iran", Journal of Applied Ichthyology, 32(6), 13681370, 2016.

[34] Freyhof, J., Weissenbacher, A. and Geiger, M., "Aphanius kruppi, a new killifish from Oman with comments on the A. dispar species group
(Cyprinodontiformes: Aphaniidae)", Zootaxa 4338 (3), pp. 557-573, 2017.

[35] Anonymous, "Yeşilırmak Havzası Toprakları", Köy İşleri Bakanlığl, Toprak Su Genel Müdürlüğü, Havzo nu: 14, Raporlar Serisi: 29. Ankara. 1970.

[36] Froese, R. and D. Pauly. Editors. FishBase. Retrieved October 10, 2015, from World Wide Web electronic publication: http://www.fishbase.org/. 2015.

[37] Küçük,F., “Türkiye'deki Bazı İçsu Balıklarının Dünya Doğayı Koruma Birliği (IUCN) Ölçütlerine Göre Değerlendirilmesi", I. Balıklandırma ve Rezervuar Yönetimi Sempozyumu, Şubat. 2006.

[38] Anonymous "IUCN Red List", www.iucnredlist.org (Haziran 2014) 2014.

[39] Nelson, J.S., "Fishes of the World", Fourth Edition, New York,U.S.A., 2006. 